\title{
Prioritization of Natural Dye Selection In Batik Tulis Using AHP And TOPSIS Approach
}

\author{
Ahmad Abdul Chamid*1, Alif Catur Murti ${ }^{2}$ \\ ${ }^{1,2}$ Informatics Engineering, Muria Kudus University, Kudus, Central Java, Indonesia \\ e-mail: *1 abdul.chamid@umk.ac.id,,$\underline{2}$ alif.catur@umk.ac.id
}

\begin{abstract}
Abstrak
Pemilihan bahan pewarna alami batik tulis menjadi prioritas utama bagi pengrajin batik tulis, pemilihan bahan pewarna alami yang tepat berpengaruh terhadap warna, corak, dan kecerahan kain batik tulis. Kombinasi metode AHP dan TOPSIS digunakan untuk memilih bahan pewarna alami batik tulis lasem. Metode AHP digunakan untuk menentukan bobot masing-masing kriteria. Metode TOPSIS digunakan untuk menentukan prioritas alternatif. Berdasarkan hasil penelitian metode TOPSIS dapat digunakan untuk menentukan prioritas alternatif bahan pewarna alami batik tulis. Berdasarkan perhitungan metode TOPSIS alternatif ke-4 (A4=Kayu Secang) mendapatkan nilai prioritas =0,8478. Kayu Secang direkomendasikan untuk para pengrajin batik tulis yang ingin memanfaatkan bahan pewarna alami.
\end{abstract}

Kata kunci-AHP, TOPSIS, Batik tulis.

\begin{abstract}
Batik is the most popular tradisional cloth made using the wax-resist dyeing technique. The fabric is found in various city in Indonesia, one of them is Lasem which popular with handdrawn batik is called Batik Tulis Lasem. Natural dye selection is one of the most important priority for the batik tulis craftsmen. Natural dyes made from leaves and flowers. Proper selection of natural dye will impact on color, motif, and brightness on batik tulis fabric. AHP and TOPSIS methods can be used together to selecting natural dye especially the batik tulis lasem. AHP method is used in determining the weights of the criteria, and then TOPSIS method is needed for determining the best alternative on natural dye of batik tulis. According to the result of research, TOPSIS method is used to determine the priority of alternative on natural dye. Based on calculation with TOPSIS method, the fourth alternative (A4 is kayu secang) get priority value is 0.8478 , so kayu secang is recommended to the craftsmen that will used this material as the natural dye.
\end{abstract}

Keywords-AHP, TOPSIS, Batik Tulis. 


\section{INTRODUCTION}

Color is the one of three aspects when those interested in buying batik tulis to choose the best fabrics. Color is beautiful spirit of batik tulis. The beauty of batik can be seen from brightness color and it can't easily fade when washed. A natural dye is necessary on process coloring so it is the main ingredient and demands for the batik tulis lasem craftsmen. Waste resulting form natural dye claimed to not pollute the environment and and proven to produce lower emissions, so the batik tulis craftsmen are expected to be able to choose natural dye appropriately [1]. Moreover competition among the craftsmen can be seen when they are selecting natural dye for producing batik tulis. Mostly, the craftsmen problem is difficulty in determining a natural dye for coloring the batik tulis, based on this problem, so in this research necessary to make a application system for the batik tulis craftsmen when they are difficult to selecting natural dye.

There are several solution approaches to the natural dye selection problem in the literature, e.g. AHP. This method applied because can used to analysis data and to assign the weight to the criteria. Many the decision support application system applied in the industrial world have principle on the evaluating criteria using AHP, because this method capable to evaluating the qualitative and quantitative criteria[2].

AHP method used to calculate weighting for the several the criteria, moreover this method capable to calculate the consistency and unconsistency the weighting matrix for each criteria. This method can also to help decision making for determine the best criteria from the several exsisting criteria[3]. AHP method have been use to determining the weight of each criteria and used to assign the alternative priority natural dye, Hartini [1] AHP method to be able to analyze comparative criteria and alternative. AHP method can be used together with Borda method for assign weight each criteria and sub criteria from each alternative, whereas Borda method used to combine the result of priority from each decision maker in order to obtain alternative priority[4]. The AHP have poorless if this method applied for the problem having use multiple alternative and criteria [5]. In order to cover the weakness of method is, with takes combination with other methods is TOPSIS. This method have applied to determine unhealthy house priority [6], and from this research, resulted is TOPSIS method can be applied to determining home conditions priority.

Now days, has many of research about decision support system which implements AHP method, on several special problem needed combine with other method. Wang and Yang have implements AHP method which combine with PROMETHEE, in this research AHP used to assest comparative criteria and using PROMETHEE to produce alternative priority[7]. TOPSIS method have been combine with Borda, Saputra and Wardoyo [8] TOPSIS method used to take decision from each the judgment, and Borda method used to combine decision from each the judgment in order to get the best alternative.

In making decision must be producing the objective alternative. It is beside on many criteria which have been used. The combination Fuzzy AHP versus Fuzzy TOPSIS used to evaluating treasury performance. Fuzzy AHP used to calculate the weight of criteria. Fuzzy TOPSIS used to determining the alternative priority level. Shaverdi [9] also developing model for decision support using Fuzzy AHP and Fuzzy TOPSIS to evaluating treasury performance and designing a methodology to evaluating performance order to more precision and useful for stakeholder. The combination AHP method and TOPSIS can implemented on decision support system to selecting teacher achievement. Juliyanti [10] also using AHP to calculate weight of criteria with consistency testing and unconsistency of value getting from the experts.

Implementation AHP method and Fuzzy TOPSIS are capable to recommend the alternative for decision maker, so process selecting alternative do to effective, and getting the

IJCCS Vol. 12, No. 2, July 2018: $129-138$ 
decision more objective [11]. Nevertheless, Hartini [1] only AHP method for selecting natural dye of Batik Tulis, in this research will combinating AHP and TOPSIS methods to determining natural dye of Batik Tulis. AHP method used to get the weight of criteria, and then it is used to determining the alternative for natural dye of Batik Tulis.

\section{METHODS}

The method used in this research is do to combinating AHP method and TOPSIS. The step of this study are : 1) the analysis of problems, 2) colleting data, 3) analysis and development system, 4) analysis data using AHP and TOPSIS.

\subsection{Analytic Hierarcy Process (AHP)}

AHP is the method was developed by Saaty and it is used to identifying data, and capable to give estimation of interaction system with overall [12]. Saaty [13] was explain several component on AHP method, such as :

1. Ratio scale, proportionality and normalized.

2. Pairwise comparison

3. The Sensitivity of the Priority eigen vector

4. clustering and using pivots to extend the scale

5. Synthesis to create a one-dimentional ratio scale for representing the overall result.

6. Rank preservation and reversal

7. Intergrating group judgments.

Tominanto [12] said, the procedure on AHP method are :

1. Analysis the hieararcy of problems.

To analyze of hierarcy with determining outcome which is the top target system.

2. Determining the priority of element.

a. The first step on determining the priority of element is making pairwise comparison, it is comparison the pair of element according with the criteria and then using the matriks.

b. Set the matriks using the element for representing relative importance of each element with other with gradation scale from 1 to 9.

c. Synthesis, to create a judgements of pairwise comparison to get overall priority

d. To scale the consistency, it is represented on equation 1 .

$$
C I=\frac{(\lambda \max -n)}{n}
$$

Where :

CI : Consistency Index

$\lambda \max :$ maximum of eigenvalue

$\mathrm{n} \quad$ : elements

$$
C R=\frac{C I}{R C}
$$

Where :

CR : Consistency ratio

CI : Consistency Index

RC : Random consistency 
A random matrix with numerical value scale 1 to 9 and ratio derived as random consistency (RC).

\subsection{TOPSIS}

TOPSIS is the method which have multicriteria, it is used to identifying solution from set of alternative beside on minimalization of simultaneous from distance the ideal point and to maximizing distance from the low point. TOPSIS can mixed the weight of relative criteria [14]. This is steps on TOPSIS [15] method, such as :

1. Determining the decision matrixs was normalized (R), it is represented on equation 3 .

$$
r_{i j}=\frac{x_{i j}}{\sqrt{\sum_{j=1}^{m} 1_{i j}^{2}}},(i=1,2, \ldots, n ; j=1,2, \ldots, m)
$$

Where :

$\mathrm{x}_{\mathrm{ij}} \quad$ :rating performance of the $i$ alternative according to the $j$ attribute.

$\mathrm{r}_{\mathrm{ij}} \quad$ :element of decision matrix was normalized.

2. Determining the decision matrixs which weighty $(\mathrm{Y})$, represented on equation 4 .

$$
y=\left[\begin{array}{ccc}
y_{11} & y_{12} & \ldots y_{i j} \\
y_{21} & y_{22} & \ldots y_{2 j} \\
\vdots & \vdots & \ddots \\
y_{i 1} & y_{i 2} \ldots & y_{i j}
\end{array}\right] \text { untuk } y_{i j}=w_{j} r_{i j}
$$

Where $w_{j}$ is the weight of criteria $j$, and $y_{i j}$ is the elemen of decision matrix was normalized and weighted.

3. Determining positif ideal solution matrix $\left(\mathrm{A}^{+}\right)$and negative ideal solution matrix $\left(\mathrm{A}^{-}\right)$, represented on equation 5 and 6.

$$
\begin{aligned}
& A^{+}=\left(y_{1}{ }^{+}, y_{2}{ }^{+}, \ldots, y_{j}{ }^{+}\right) \\
& A^{-}=\left({y_{1}}^{-}, y_{2}{ }^{-}, \ldots, y_{j}{ }^{-}\right)
\end{aligned}
$$

With,

$$
\begin{aligned}
& y_{j}^{+}=\left\{\begin{array}{c}
\max \\
i \quad y_{i j}, \text { if } j=\text { benefit } \\
\min _{i} y_{i j}, \text { if } j=\cos t
\end{array}\right. \\
& y_{j}{ }^{-}=\left\{\begin{array}{c}
\max _{i} y_{i j}, \text { if } j=\text { benefit } \\
\min _{i} y_{i j}, \text { if } j=\text { cost }
\end{array}\right.
\end{aligned}
$$

4. determining distance of the alternative value from positif ideal solution matrix $\left(\mathrm{d}_{\mathrm{i}}^{+}\right)$and negative ideal solution matrix $\left(\mathrm{d}_{\mathrm{i}}{ }^{-}\right)$, distance positif ideal solution $\left(\mathrm{d}_{\mathrm{i}}^{+}\right)$is represented on equation 9 .

$d_{i}^{+}=\sqrt{\sum_{j=1}^{m}\left(y_{i j}-y_{j}^{+}\right)^{2}}$

Where, 
$y_{j}{ }^{+} \quad$ : element of positif ideal solution matrix, for distance negative ideal solution matrix $\left(\mathrm{d}_{\mathrm{i}}^{-}\right)$represented on equation 10.

$d_{i}^{-}=\sqrt{\sum_{j=1}^{m}\left(y_{i j}-y_{j}{ }^{-}\right)^{2}}$

Where,

$y_{j}{ }^{-} \quad$ : element of negative ideal solution matrix

5. determining preference value (ci) for each alternative. The Preference value is closeness of alternative on ideal solution, it is represented on equation 11.

$c_{i}=\frac{d_{i}^{-}}{d_{i}^{-}+d_{i}^{+}}$

Where,

Value of $c i$ is more than describe a alternative priority.

\section{RESULTS AND DISCUSSION}

For the selecting natural dye of batik tulis using six criteria, they are represented on table 1 . The criteria was describe on Table 1 will comparing to each other with natural dye and then weighted by the expert natural dye of batik tulis. Next step, the weighted data result will be analyzed using AHP, and the result can be seen on Table 2 (show value of the priority vector describe the weighted result). From this result can be shown that the criteria (K5 = result color) is the most valuable or it is called the priority for the selecting natural dye of batik tulis.

Table 1. the criteria of natural dye

\begin{tabular}{|l|l|}
\hline Id of creteria & \multicolumn{1}{|c|}{ Name of criteria } \\
\hline K1 & Biaya \\
\hline K2 & Proses Produksi \\
\hline K3 & Bahan Baku \\
\hline K4 & Dampak Lingkungan \\
\hline K5 & Hasil Warna \\
\hline K6 & Tingkat Kelunturan \\
\hline
\end{tabular}

Table 2. The weighted of criteria data

\begin{tabular}{|c|c|c|c|c|c|c|r|r|}
\hline Criteria & K1 & K2 & K3 & K4 & K5 & K6 & $\begin{array}{c}\text { Result } \\
\text { of Rank }\end{array}$ & $\begin{array}{l}\text { Priority } \\
\text { Vector }\end{array}$ \\
\hline K1 & 1 & 0,33 & 3 & 5 & 0,2 & 3 & 1,2009 & 0,1417 \\
\hline K2 & 3 & 1 & 5 & 3 & 0,33 & 5 & 2,0536 & 0,2422 \\
\hline K3 & 0,33 & 0,2 & 1 & 3 & 0,2 & 3 & 0,7023 & 0,0828 \\
\hline K4 & 0,2 & 0,33 & 0,33 & 1 & 0,14 & 0,33 & 0,3192 & 0,0377 \\
\hline K5 & 5 & 3 & 5 & 7 & 1 & 5 & 3,7141 & 0,4381 \\
\hline K6 & 0,33 & 0,2 & 0,33 & 3 & 0,2 & 1 & 0,4870 & 0,0574 \\
\hline Jumlah & 9,87 & 5,07 & 14,67 & 22 & 2,08 & 17,33 & 8,48 & 1,0000 \\
\hline
\end{tabular}

The weighted data was analyzed using AHP method, so it is will be calculated using index consistency ratio $(C I)$. This index used to assign level of consistency ratio which needed on a matrix normalized such as describe on Table 3. 
Table 3. The matrix normalized

\begin{tabular}{|c|c|c|c|c|c|c|c|}
\hline $\mathbf{K 1}$ & $\mathbf{K 2}$ & $\mathbf{K 3}$ & $\mathbf{K 4}$ & $\mathbf{K 5}$ & $\mathbf{K 6}$ & Total & $\begin{array}{l}\text { Eigen } \\
\text { Value }\end{array}$ \\
\hline 0,10 & 0,07 & 0,20 & 0,23 & 0,10 & 0,17 & 0,87 & 6,1296 \\
\hline 0,30 & 0,20 & 0,34 & 0,14 & 0,16 & 0,29 & 1,43 & 5,8935 \\
\hline 0,03 & 0,04 & 0,07 & 0,14 & 0,10 & 0,17 & 0,55 & 6,6050 \\
\hline 0,02 & 0,07 & 0,02 & 0,05 & 0,07 & 0,02 & 0,24 & 6,4338 \\
\hline 0,51 & 0,59 & 0,34 & 0,32 & 0,48 & 0,29 & 2,53 & 5,7701 \\
\hline 0,03 & 0,04 & 0,02 & 0,14 & 0,10 & 0,06 & 0,39 & 6,7261 \\
\hline \multicolumn{2}{|l|}{ Jumlah } & & & & & & $\mathbf{3 7 , 5 5 8 1}$ \\
\hline
\end{tabular}

Result of the matrix normalized is a maximum eigen value, it is used to calculate the index consistency ratio was describe on equation 14 .

$$
\begin{aligned}
& \text { Nilai Maksimum }=\frac{37,5581}{6}=6,2597 \\
& C I=\frac{6,2597-6}{6-1}=0,0519 \\
& C R=\frac{0,0519}{1,24}=0,0419
\end{aligned}
$$

The index consistency ratio assign with equation 3, according to AHP method if value of CR more than $0.1(\mathrm{CR}<=0,1)$ then it is call consistent or valid (equation 14) can be shown the value of $\mathrm{CR}$ is 0.0149 so weighted from the expert can be said valid or consistent.

The result of weighted criteria was produce from before step, next the data can be analyzed using TOPSIS. This method used to assign the alternative priority of natural dye. The weighted data and each criteria can be shown on Table 4 . Table 5 describe the data of the alternative natural dye.

Table 4. The Weighted Criteria and value of assignment

\begin{tabular}{|c|c|c|c|c|c|c|}
\hline Criteria & K1 & K2 & K3 & K4 & K5 & K6 \\
\hline weight & 0,1417 & 0,2422 & 0,0828 & 0,0377 & 0,4381 & 0,0574 \\
\hline $\begin{array}{c}\text { assignme } \\
\text { nt }\end{array}$ & Cost & Benefit & Cost & Benefit & Cost & Benefit \\
\hline
\end{tabular}

Table 5. Data Alternative of natural dye

\begin{tabular}{|l|l|}
\hline id Alternative & Name of Alternative \\
\hline A1 & Kayu Nangka \\
\hline A2 & Kayu Tingi \\
\hline A3 & Kayu Jelawe \\
\hline A4 & Kayu Secang \\
\hline A5 & Daun Tom \\
\hline
\end{tabular}


From the The alternative matrix comparison data, so it is will be the normalized matrix, which show on Tabel 7.

Table 7. The normalized matrix

\begin{tabular}{|c|c|c|c|c|c|c|}
\hline \multirow{2}{*}{ Alternative } & \multicolumn{7}{|c|}{ criteria } \\
\cline { 2 - 7 } & K1 & K2 & K3 & K4 & K5 & K6 \\
\hline A1 & 0,3162 & 0,2425 & 0,2041 & 0,4472 & 0,5774 & 0,4472 \\
\hline $\mathbf{A 2}$ & 0,5270 & 0,4851 & 0,4082 & 0,4472 & 0,5774 & 0,4472 \\
\hline $\mathbf{A 3}$ & 0,4216 & 0,4851 & 0,6124 & 0,4472 & 0,3849 & 0,4472 \\
\hline $\mathbf{A 4}$ & 0,2108 & 0,4851 & 0,6124 & 0,4472 & 0,1925 & 0,4472 \\
\hline $\mathbf{A 5}$ & 0,6325 & 0,4851 & 0,2041 & 0,4472 & 0,3849 & 0,4472 \\
\hline
\end{tabular}

The result from calculate matrix normalized will multiplied with weight of each criteria, and show on Table 8.

Table 8. The Result of multiplied with weight of creteria

\begin{tabular}{|c|c|c|c|c|c|c|}
\hline \multirow{2}{*}{$\begin{array}{c}\text { Alternativ } \\
\text { e }\end{array}$} & \multicolumn{6}{|c|}{ Criteria } \\
\cline { 2 - 7 } & K1 & K2 & K3 & K4 & K5 & K6 \\
\hline A1 & 0,0448 & 0,0587 & 0,0169 & 0,0169 & 0,2529 & 0,0257 \\
\hline $\mathbf{A 2}$ & 0,0747 & 0,1175 & 0,0338 & 0,0169 & 0,2529 & 0,0257 \\
\hline $\mathbf{A 3}$ & 0,0597 & 0,1175 & 0,0507 & 0,0169 & 0,1686 & 0,0257 \\
\hline $\mathbf{A 4}$ & 0,0299 & 0,1175 & 0,0507 & 0,0169 & 0,0843 & 0,0257 \\
\hline $\mathbf{A 5}$ & 0,0896 & 0,1175 & 0,0169 & 0,0169 & 0,1686 & 0,0257 \\
\hline
\end{tabular}

After we know the result of multiplied with weight of criteria, so we can using it to looking for distance of positive ideal solution from each alternative. The result of calculate distance of positif ideal solution dan negative ideal solution can be shown on Tabel 10.

The distance of positif ideal solution and negative ideal solution can be show on Table 10 , and then will used to assign the alternative priority. The result of calculate it can be shown on Table 11.

Table 10. The Distance of positif and negative ideal solution

\begin{tabular}{|c|c|c|}
\hline \multirow{2}{*}{ Alternative } & \multicolumn{2}{|c|}{$\begin{array}{c}\text { Distance Ideal } \\
\text { Solution }\end{array}$} \\
\cline { 2 - 3 } & D+ & D- \\
\hline A1 & 0,1792 & 0,0561 \\
\hline A2 & 0,1753 & 0,0629 \\
\hline A3 & 0,0956 & 0,1070 \\
\hline A4 & 0,0338 & 0,1883 \\
\hline A5 & 0,1033 & 0,1082 \\
\hline
\end{tabular}


Table 11. The Alternative priority

\begin{tabular}{|c|c|}
\hline Alternative & $\begin{array}{c}\text { Value of } \\
\text { priority }\end{array}$ \\
\hline A1 & 0,2385 \\
\hline A2 & 0,2641 \\
\hline A3 & 0,5281 \\
\hline A4 & 0,8478 \\
\hline A5 & 0,5114 \\
\hline
\end{tabular}

According to Tabel 11 we know that the fourth alternative ((A4= Kayu secang) is the best alternative or the priority of alternative. It is can used to natural dye with value $=0.8478$, with cost classified cheap, Rp. 10.000/kg, and have complexity level middle, the process production is easy, and the Batik Tulis craftsmen have more acknowlagement about the utilization of Kayu Secang as natural dye.

Detail of kayu secang material, it is more easy to get in area of Batik Tulis craftsmen, so if we seen from the side of material, Kayu Secang is classified easy to get. and the next for environtment effect result, the smels of this material does not sting, so kayu secang can be classified sustainable. For the result of color from kayu secang is stabil, and commonly batik tulis which using natural dye for the material usually produce soft color, nevertheless from the side of stable color is good, not easy faded althougt often washed, over to the sun and ironed. So according to Table 11 Kayu Secang is recommended for the craftsmen use to natural dye.

\section{CONCLUSIONS}

According to the result of this research, combination two method is AHP and TOPSIS can be use to assign the natural dye of Batik Tulis. Form the data result in this research getting six criteria. It is can be used to assign the natural dye. AHP method used to determinating the weighted of each criteria, such as can be seen on Tabel 2. From the result of weigted can be shown that the color result is the priority comparison while determining natural dye and getting priority value $=0.4381$, it is hightest to other criteria. After do to calculate the consistency ratio, the result is consistent. Based on the result of this study TOPSIS can be used to assign the alternative priority form natural dye. From five alternative was get, the alternative is Kayu Secang (fourth alternative, A4 = Kayu Secang) get priority value $=0.8478$, so Kayu Secang is recommended for the Batik Tulis craftsmen as a priority Natural Dye.

\section{ACKNOWLEDGEMENTS}

This research has been funded by The Direktorat Penelitian dan Pengabdian Kepada Masyarakat (DPRM) Ministry of National Education, Lembaga Penelitian (Lemlit) Universitas Muria Kudus, Batik Sumber Rejeki Lasem Rembang - Central Java. We would like to thank for help and support for paid and data has been given, so that we can complete this research.

IJCCS Vol. 12, No. 2, July 2018 : $129-138$ 


\section{REFERENCES}

[1] S. Hartini, S. Nurmalasari, and D. I. Rinawati, "BATIK TULIS SOLO DENGAN MENGGUNAKAN METODE ANALYTICAL HIERARCHY PROCESS ( AHP )," J@ti Undip, vol. ix, no. 2, pp. 77-85, 2014.

[2] A. Akincilar and M. Dagdeviren, "A hybrid multi-criteria decision making model to evaluate hotel websites," Int. J. Hosp. Manag., vol. 36, pp. 263-271, 2014.

[3] Y. O. Ouma, J. Opudo, and S. Nyambenya, "Comparison of Fuzzy AHP and Fuzzy TOPSIS for Road Pavement Maintenance Prioritization: Methodological Exposition and Case Study," Hindawi Publ. Corp. Adv. Civ. Eng., 2015.

[4] D. N. Ilham and S. Mulyana, "Sistem Pendukung Keputusan Kelompok Pemilihan Tempat PKL mahasiswa dengan Menggunakan Metode AHP dan Borda," IJCCS (Indonesian J. Comput. Cybern. Syst., vol. 11, no. 1, pp. 55-66, 2017.

[5] S. Rouhani, M. Ghazanfari, and M. Jafari, "Evaluation model of business intelligence for enterprise systems using fuzzy TOPSIS," Expert Syst. Appl., vol. 39, no. 3, pp. 37643771, 2012.

[6] A. A. Chamid, "PENERAPAN METODE TOPSIS UNTUK MENENTUKAN PRIORITAS KONDISI RUMAH,” Simetris, vol. 7, no. 2, pp. 537-544, 2016.

[7] J. Wang and D. Yang, "Using a hybrid multi-criteria decision aid method for information systems outsourcing," Comput. Oper. Res., vol. 34, pp. 3691-3700, 2007.

[8] M. A. Budhi and R. Wardoyo, "Group Decision Support System Determination Of Best Employee Using Topsis And Borda," IJCCS (Indonesian J. Comput. Cybern. Syst., vol. 11, no. 2, pp. 165-176, 2017.

[9] M. Shaverdi, I. Ramezani, R. Tahmasebi, A. Asghar, and A. Rostamy, "Combining Fuzzy AHP and Fuzzy TOPSIS with Financial Ratios to Design a Novel Performance Evaluation Model," Int. J. Fuzzy Syst., vol. 18, no. 2, pp. 248-262, 2016.

[10] Juliyanti, M. I. Irawan, and I. Mukhlash, "PEMILIHAN GURU BERPRESTASI MENGGUNAKAN METODE AHP DAN TOPSIS," in Prosiding Seminar Nasional Penelitian, Pendidikan dan Penerapan MIPA, Fakultas MIPA, Universitas Negeri Yogyakarta, 2011, pp. 63-68.

[11] A. Muhardono and R. R. Isnanto, "Penerapan Metode AHP dan Fuzzy Topsis Untuk Sistem Pendukung Keputusan Promosi Jabatan,” J. Sist. Inf. Bisnis, vol. 2, pp. 108-115, 2014.

[12] Tominanto, "SISTEM PENDUKUNG KEPUTUSAN DENGAN METODE ANALYTICAL HIERARCHY PROCESS (AHP) UNTUK PENENTUAN PRESTASI KINERJA DOKTER PADA RSUD. SUKOHARJO,” INFOKES, vol. 2, no. 1, pp. 1-15, 2012.

[13] T. L. Saaty and L. G. Vargas, "Models, methods, concepts \& applications of the analytic hierarchy process," Springer Sci. Bus. Media, vol. 175, 2012.

[14] D. L. Olson, "Comparison of Weights in TOPSIS Models," Math. Comput. Model., vol. 40, pp. 721-727, 2004. 
[15] A. Suryandini and Indriyati, "Sistem Pendukung Keputusan Untuk Penentuan Minat peserta Didik di SMA Menggunakan Metode Topsis," J. Masy. Inform., vol. 6, no. 11, pp. 30-37, 2014. 